\title{
Pengembangan Arsitektur Data Sistem Informasi Pondok Pesantren
}

\author{
Nanda Ayu Istiqomah', Khoirotul Imayah², Nuris Saidah ${ }^{3}$, Muhammad Ainul Yaqin ${ }^{4}$ \\ Jurusan Teknik Infromatika, Fakultas Sains dan Teknologi Universitas Islam Negeri Maulana Malik \\ Ibrahim Malang \\ Jalan Gajayana No. 50 Malang 65144 Telp. +62(341) 551-354 \\ nandaayuistiqomah23@gmail.com,khoirotul.xtkj@gmail.com,nurissaidah06@gmail.com, \\ yaqinov@ti.uin-malang.ac.id
}

\begin{abstract}
Data management is very necessary in an institution to facilitate data processing. One of them is Islamic education institutions or Islamic boarding schools that have developed nformation systems for Islamic boarding school. In building a boarding school information system, applications and data are needed. Data architecture obtained from a hierarchy of information systems consisting of executive information systems, management informations systems, and transaction processing systems. Architecture design of information systems for Islamic boarding school is done by building an ERD (Entity Relationship Diagram) from a collection of data needed on boarding school information systems. ERD is a database building model by describing relations between database entities.
\end{abstract}

Keywords: Data Architecture, Islamic Boarding School Infromation System, Entity Relationship Diagram

\begin{abstract}
Abstrak
Manajemen data sangat diperlukan pada suatu lembaga agar memudahkan pengolahan data. Salah satunya pada lembaga pendidikan islam atau pondok pesantren yang telah mengembangkan sistem infromasi pondok pesantren. Dalam membangun sistem infromasi pondok pesantren dibutuhkan aplikasi dan data yang saling terhubung satu sama lain. Arsitektur data diperoleh dari hirarki sistem informasi yang terdiri dari sistem informasi eksekutif, sistem infromasi manajemen, dan sistem pengolah transaksi. Perancangan arsitektur data sistem informasi pondok pesantren dilakukan dengan membangun ERD (Entity Relationship Diagram) dari sekumpulan data yang dibutuhkan pada sistem informasi pondok pesantren. ERD merupakan model penyusun basis data dengan menggambarkan relasi antar basis data.
\end{abstract}

Kata kunci: Arsitektur Data, Sistem Informasi Pondok Pesantren, ERD (Entity Relationship Diagram.

\section{PENDAHULUAN}

Pendidikan merupakan sektor yang sangat penting dalam menciptakan sumber daya manusia, dan sangat penting bagi masyarakat sekarang. Belajar di ondok pesantren atau pendidikan agama yang seharusnya diajarkan kepada anakanak sejak dini. Dan terdapat beberapa tipe pondok pesantren yang belum menerapkan sistem informasi. Pondok pesantren di analogikan sebagai enterprise yang bergerak dibidang pendidikan islam yang mana memberikan kontribusi untuk anak bangsa dalam melanjutkan jenjang pendidikan. Sistem informasi pondok pesantren tentang belajar mengajar sebagai bagian dari sektor pendidikan, masih belum dikelolah dengan baik oleh pihak pondok pesantren. Penanganan dan pegelolahan data sebagian pondok pesantren masih menggunakan manual, pencarian data lampau yang membutuhkan waktu lama, sehingga belum terkoordinasi dengan baik setiap bagian yang terlibat didalamnya. Hal-hal tersebut menyebabkan nilai kinerja manajemen pondok pesantren belum 
mencapai optimal. Oleh karena itu dibutuhkan sistem infromasi yang terintegrasi dan dapat mengelolah informasi administrasi secara cepat dan tepat dengan dukungan perangkat lunak komputer.

Dalam pembuatan sistem informasi ada penerapakn aritektur data sistem informasi yang mana dapat membantu dalam rancangan pengembangan sistem informasi. Penerapan arsitektur data sistem informasi pondok pesantren dapat menggunakan konsep ERD (Entity Relationship Diagram) yang merupakan suatu model unntuk menjelaskan hubungan antara data dalam basis data berdasarkan objek-objek dasar data yang mempunyai hubungan anata relasi, yang mana dapat membantu dalam pembuatan pemodelan arsitektur bisnis untuk sistem infromasi pondok pesantren.

\section{METODOLOGI PENELITIAN}

\subsection{Sistem Informasi Pondok Pesantren}

Sistem Informasi adalah sebuah sistem buatan manusia yang terdapat berbagai komponen dalam suatu organisasi dan bertujuan untuk menyajikan informasi [1], dapat disimpulkan sistem informasi adalah sebuah software, hardware, data dan jaringan komunikasi yang terorganisasi untuk mrngumpulkan, memasukkan, mengolah menyimpan data, dan melaporkan infromasi sebagai pendukung pengambilan keputusan atau tutjuan suatu organisasi tersebut.

Lembaga Pendidikan mengenal Pesantren sebagai Lembaga Pendidikan Islam yang di dalamnya terdapat proses belajar mengajar agama Islam dan sebagai media untuk menyebarkan ilmu agama. Pesantren mempunyai sistem pendidikan tersendiri. [2] Mulanya tersebar hanya di beberapa desa, namun seiring berkembangnya zaman, pesantren mengalami modernisasi, pesantren dianggap sebagai lembaga pendidikan yang mencakup runag lingkup yang kompleks, untuk memenuhi standar nasional pondok pesantren, butuh beberapa proses pengembangan arsitektur data sistem informasi pondok pesantren agar menjadi lembaga pendidikan islam yang layak dan memadai.

\subsection{Arsitektur Data}

Arsitektur data merupakan runtutan yang di dalamnya terdapat kerangka dengan menjelaskan secara detail bagaimana data dapat berpindah melalui sistem yang digunakan oleh sebuah organisasi. Arsitektur data bertujuan untuk membangun entitas secara keseluruhan dengan membuat relasi dan atribut yang memiliki integrasi dengan entitas data dan atribut lain. [4] Langkah membangun sebuah arsitektur data, dapat dilakukan dengan mencatat seluruh data yang menjadi entitas data, membuat relasi data yang di tabel entitas data, serta mendefinisikan relasi, atribut dan entitas untuk memperjelas proses bisnis yang ada dalam sebuah organisasi. 


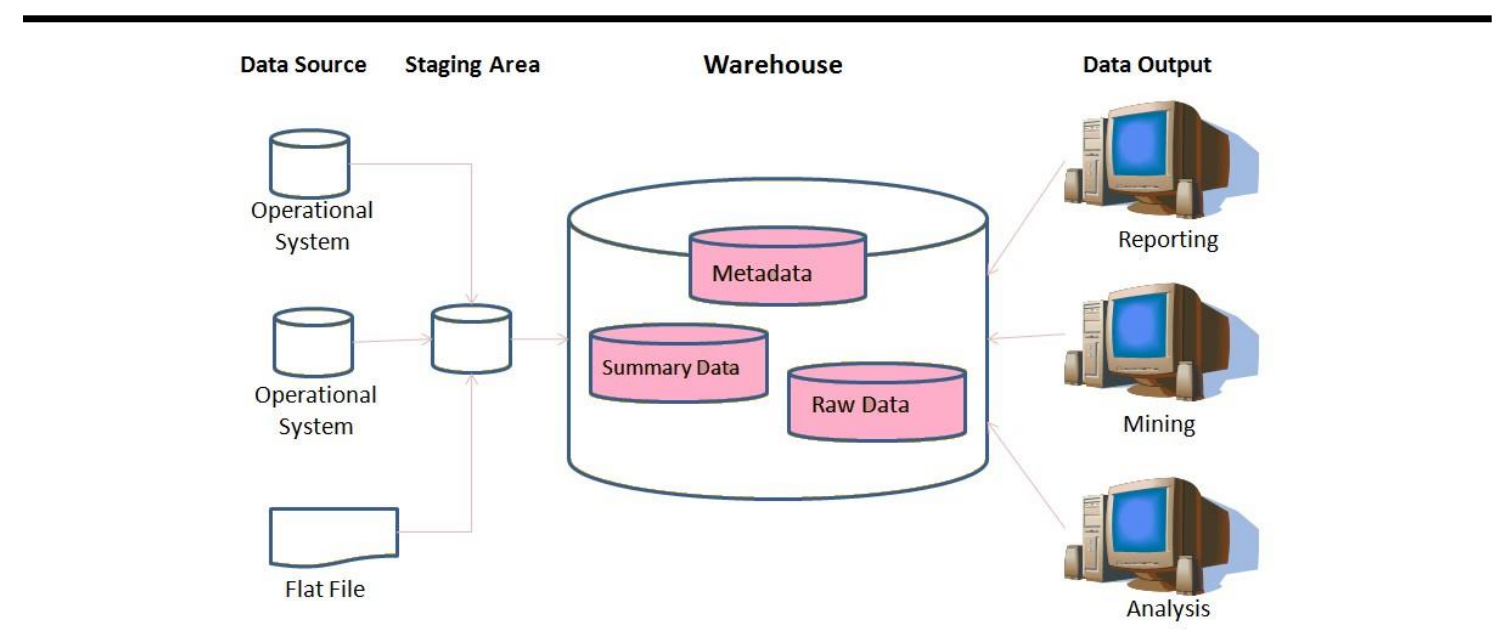

Gambar 1 Contoh Arsitektur Data

\subsection{ERD (Entity Relationship Diagram)}

Entity Relationship Diagram merupakan jaringan yang memiliki susunan data yang tersimpan di sistem secara abstrak. [4] ERD adalah alat perancangan untuk memodelkan suatu basis data. Tujuan dibuatnya ERD dalam suatu organisasi adalah untuk pemodelan yang menunjukkan hubungan antar data yang mempunyai relasi, juga mendokumentasikan data yang ada dengan cara menjelaskan tiap masing-masing data dan relasinya. Kardinalitas Relasi adalah jumlah maksimum entitas yang dapat berelasi (berhubungan) dengan entitas pada himpunan entitas yang lain.

Penelitian ini dilakukan melalui pendekatan kuantitatif dengan mengumpulkan data-data yang diperlukan. [5] Menyatakan bahwa metode penelitian kuantitatif merupakan suatu cara yang digunakan untuk menjawab masalah penelitian yang berkaitan dengan data berupa angka dan program statistik. Tujuan penelitian kuantitatif adalah mengembangkan dan menggunakan model-model matematis, teori-teori dan/atau hipotesis yang berkaitan dengan fenomena alam. Tahapan dari penelitian ini dapat dilihat pada bagan dibawah ini, diantaranya adalah:

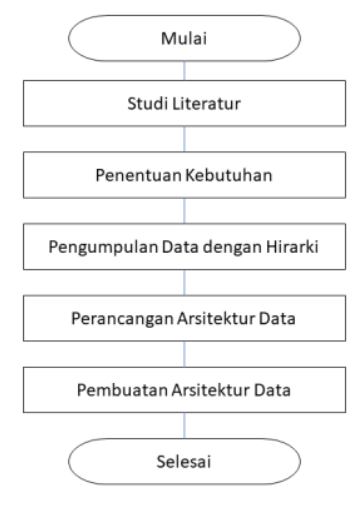

Gambar 2. Tahapan Penelitian 


\section{a. Studi Literatur}

Mempelajari teori-teori dan penelitian yang berkaitan dengan arsitektur data sistem informasi dari berbagai sumber seperti buku, paper, maupun media internet yang terpercaya.

\section{b. Penentuan Kebutuhan}

Mendefiniskan hal-hal yang dibutuhkan dalam penelitian mulai dari data yang dibutuhkan hingga kebutuhan untuk merancang arsitektur data pondok pesantren.

\section{c. Pengumpulan Data menggunakan Hirarki}

1. Data yang dibutuhkan dalam pengembangan arsitektur data pondok pesantren berdasarkan kebutuhan pondok pesantren adalah 52 standar nasional. Berikut ini adalah 52 standar nasional pondok pesantren tersebut:

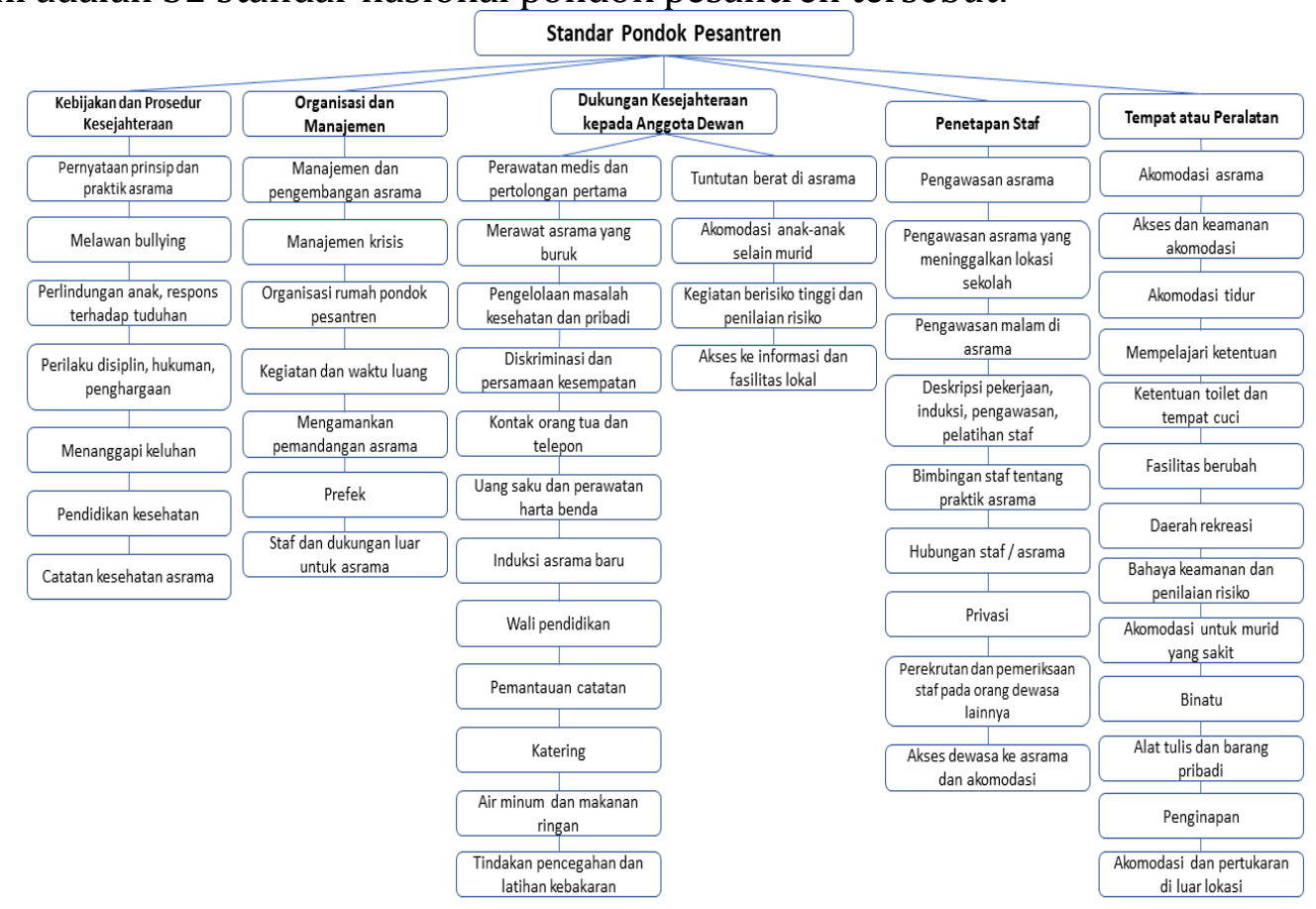

Gambar 3. 52 Standar Nasional Pondok Pesantren

2. Data Hirarki, Data Hirarki adalah sebuah proses pengelompokan data yang mana digunakan untuk memudahkan pembuatan model arsitektur data yang ada pada pondok pesantren dan diimplementasikan dengan membuat ERD (Entity Relationship Diagram). Berikut ini adalah proses hirarki arsitektur data: 


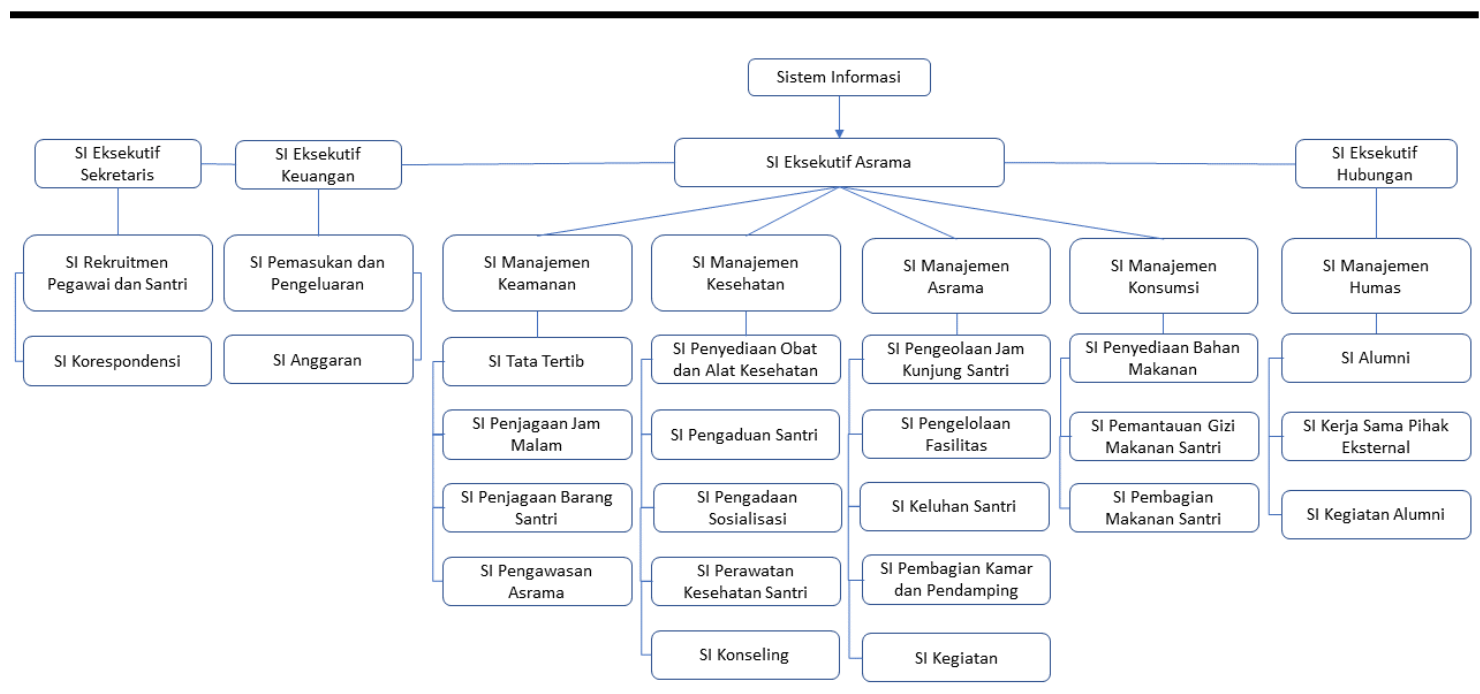

Gambar 4. Proses data hirarki

\section{d. Perancangan Arsitektur Data}

Perancangan arsitektur data dalam penelitian ini yaitu membuat arsitektur data yang sesuai dengan 52 standar nasional pondok pesantren. Dalam penelitian ini, terlebih dahulu mengelompokkan data inti terlebih dahulu kemudian baru membuat rancangan dari setiap cabang sub bab. Dalam perancangan dibuatnya tabel ERD dalam suatu organisasi adalah untuk pemodelan yang menunjukkan hubungan antar data yang mempunyai relasi.

\section{e. Pembuatan Arsitektur Data}

Pembuatan arsitektur data yang dilakukan dalam penelitian ini yaitu dengan membuat rancangan arsitektur data disetiap proses bisnis yang telah dibuat untuk di implementasikan pada rancangan tabel ERD pada pondok pesantren. Pembuatan arsitektur data pondok pesantren ini guna membantu dalam pembuatan sistem infromasi pondok pesantren.

\section{HASIL DAN PEMBAHASAN}

\subsection{Arsitektur Data Sistem Informasi Eksekutif Sekertaris}

Pada arsitektur data Sistem Informasi Eksekutif Sekertaris ini terdapat 2 Sub menu pada rancangan pengumpulan data hirarki yaitu :

\section{a. Perkrutan Santri dan Staf}

Di dalam rancangan arsitektur data pada gambar diatas Tabel Data Calon Santri memiliki relasi dengan Data calon wali santri, Data Tes calon santri. Kemudian Data Calon Staf memilki relasi dengan Data Tes Calon Staf kemudian memilki relasi ke Data pengumuman yang mana di Data pengumuman ini memilki relasi dengan Data Tes calon staf kemudain untuk staf dan santri yang di terima melengkapi administrasi yang telah di tentukan.

\section{b. Administrasi Persuratan}

Di dalam rancangan arsitektur data pada gambar diatas terdapat data admin yang mana memiliki relasi dengan surat keluar dan masuk. Dan untuk surat keluar dan masuk juga memiliki relasi dengan tabel instasi. 


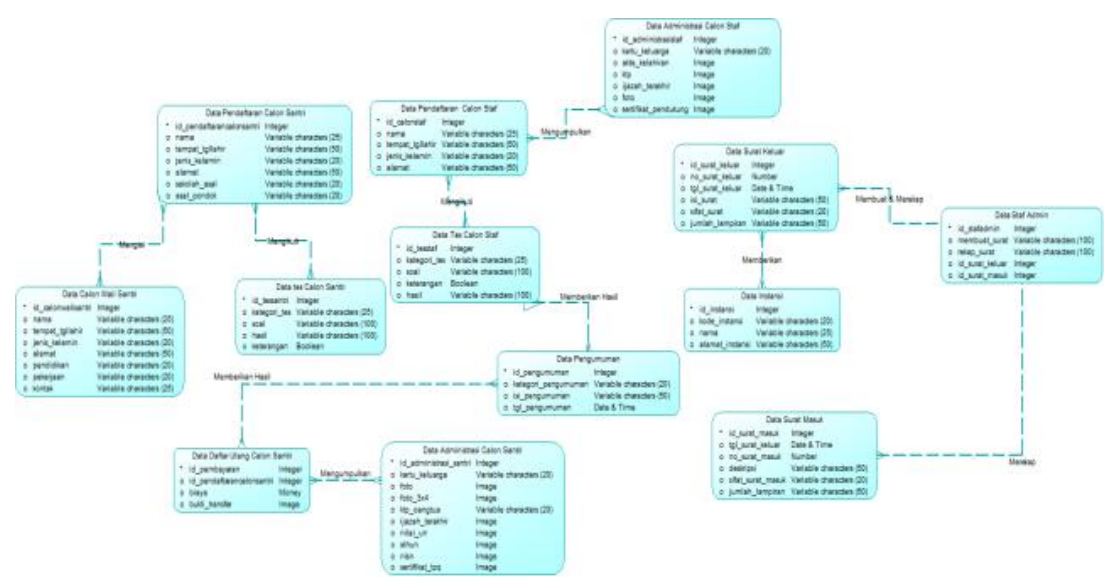

Gambar 5. Arsitektur Data Sistem Informasi Eksekutif Sekertaris

\subsection{Arsitektur Data Sistem Informasi Eksekutif Keuangan}

Di dalam rancangan arsitektur data pada gambar diatas Tabel Rekening memilki relasi dengan data pemasukan, pengeluaran, detail jurnal dan detail pembayaran yang mana. Kemudian untuk data pembayaran memilki relasi dengan detail pembayaran.

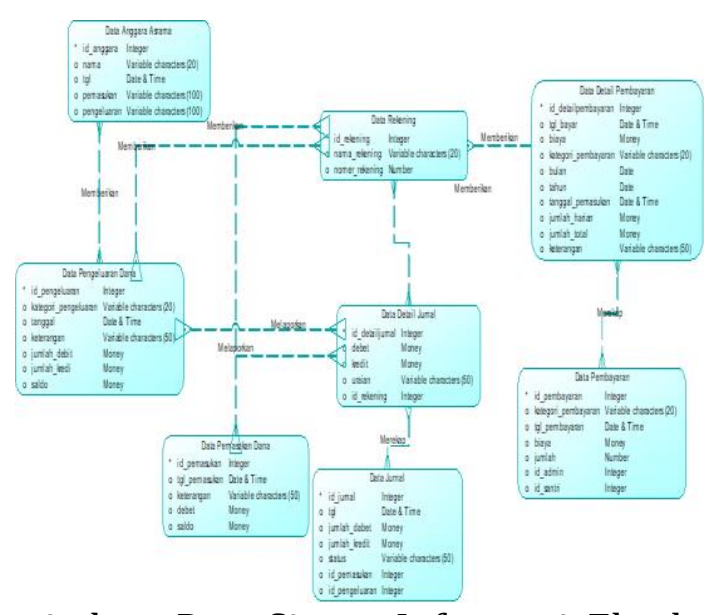

Gambar 6. Arsitektur Data Sistem Informasi Eksekutif Keuangan

\subsection{Arsitektur Data Sistem Informasi Manajemen Keamanan}

Di dalam rancangan arsitektur data pada gambar diatas Data ketertiban melibatkan data pengawas dan jadwal pengawas kemudian direlasikan pada data laporan pengawasan untuk jam malam dan barang. Dan terdapat data fasilitas dan kegiatan yang mana memiliki relasi untuk memberikan fasilitas yang dibutuhkan pada kegiatan kemanan. Kemudian ada data peraturan, pelanggaran, dan sanksi dimana memiliki relasi dengan laporan keamanan. 


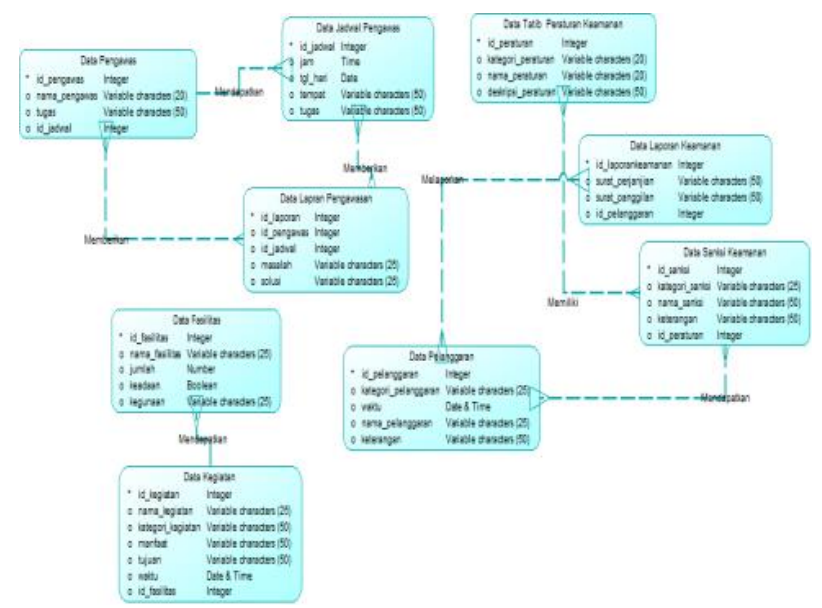

Gambar 7. Arsitektur Data Sistem Informasi Manajemen Keamanan

\subsection{Arsitektur Data Sistem Informasi Manajemen Kesehatan}

Di dalam rancangan arsitektur data pada gambar diatas Data kesehatan yang akan direlasikan pada data santri, data fasilitas dan alat, data obat dan data yang diperlukan untuk kesehatan santri, pada data santri dapat diketahui data riwayat kesehatan santri, data jadwal periksa, data masalah dan berbagai macam keluhan santri agar dapat di catat oleh petugas kesehatan dan segera dapat ditangani.

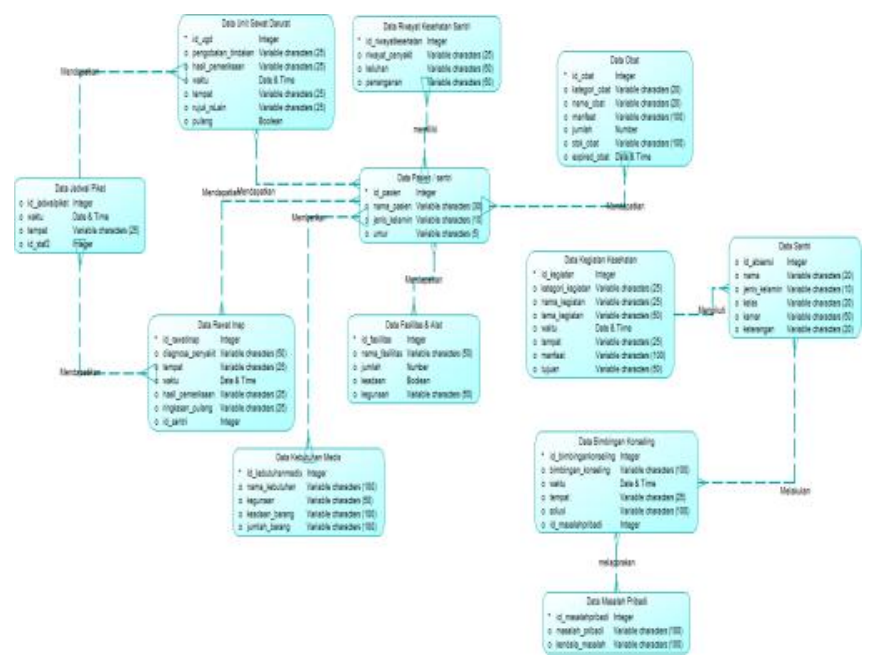

Gambar 8. Arsitektur Data Sistem Informasi Manajemen Kesehatan

\subsection{Arsitektur Data Sistem Informasi Manajemen Asrama}

Di dalam rancangan arsitektur data pada gambar diatas Data Manajemen Asrama meliputi Data Penjagaan asrama, data pegawai, data santri, data asrama yang akan direlasikan ke data jadwal penjagaan, data perbaikan dan data pencatatan keluhan yang ada di asrama. 


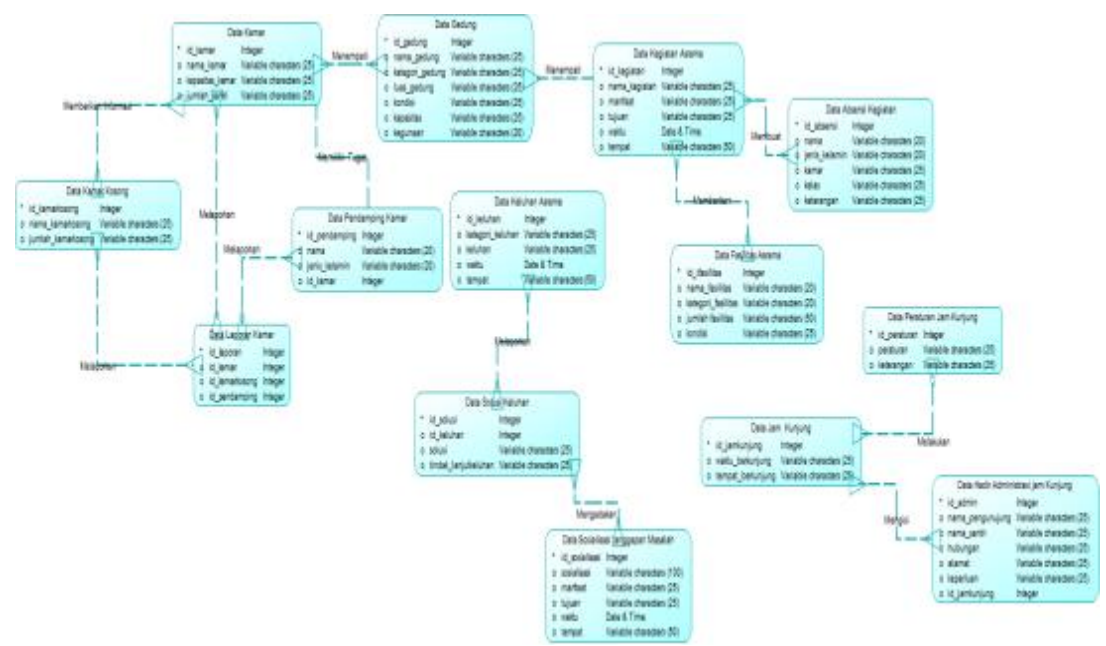

Gambar 9. Arsitektur Data Sistem Informasi Manajemen Asrama

\subsection{Arsitektur Data Sistem Informasi Manajemen Konsumsi}

Di dalam rancangan arsitektur data pada gambar diatas memilki data menu yang mana memiliki relasi dengan jadwal makan,menu tambahan, fasilitas dan alat dan pemenuhan kebutuhan konsumsi yang diperlukan untuk dari proses pembelian bahan makanan sampai proses penyajian atau pengambilan makanan di pondok pesantren. Adapun catatan masalah yang berisikan data masalah yang berbubungan dengan konsumsi santri di pondok pesantren.

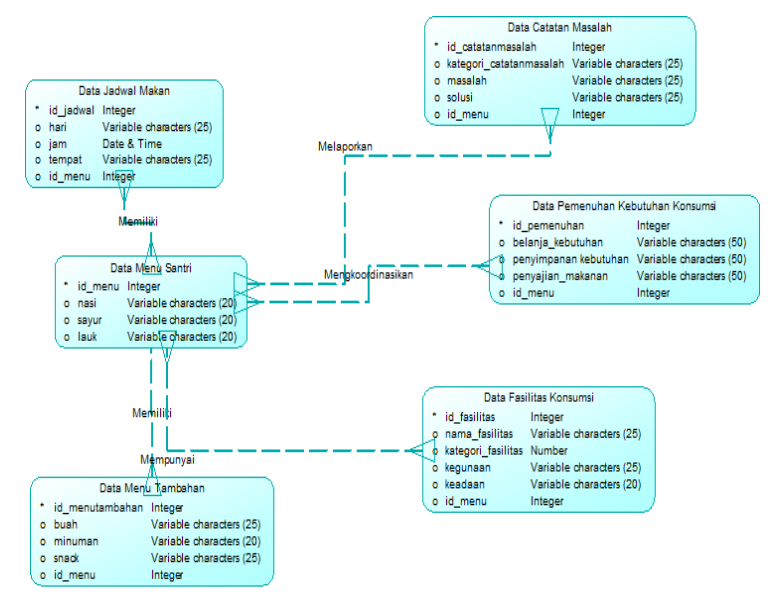

Gambar 10. Arsitektur Data Sistem Informasi Manajemen Konsumsi

\subsection{Arsitektur Data Sistem Informasi Eksekutif Hubungan}

Di dalam rancangan arsitektur data pada gambar diatas dimana terdapat Data alumi yang memiliki relasi dengan Data kegiatan alumi, undangan alumni, dokumentasi kegiatan. Kemudian untuk Data Sponsor Kegiatan memilki relasi dengan data kontribusi dan sumbangan. Kemudian untuk data berita atau informasi untuk alumni atau santri memilki relasi dengan lowongan pekerjaan. 


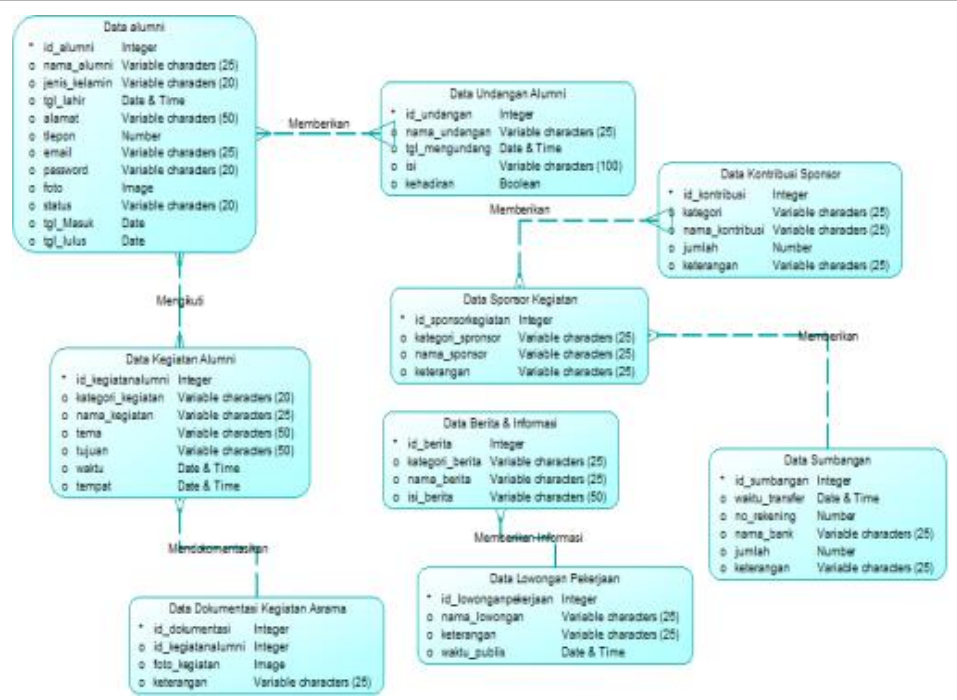

Gambar 11. Arsitektur Data Sistem Informasi Eksekutif Hubungan

\section{SIMPULAN}

Pengembangan arsitektur data pondok pesantren merupakan sistem infromasi yang terintegrasi dan dapat mengelolah informasi administrasi secara cepat dan tepat dengan dukungan perangkat lunak komputer. Integrasi data dilakukan dengan membuat model arsitektur data sistem informasi pondok pesantren, proses pembuatan model arsitektur diperoleh dari hirarki sistem informasi yang terdiri dari sistem informasi eksekutif, sistem infromasi manajemen, dan sistem pengolah transaksi. Penerapan hasil dari arsitektur data berupa ERD untuk mempermudah pemodelan arsitektur data pondok pesantren.

\section{DAFTAR PUSTAKA}

[1] Yakub, "Pengantar Sistem Infromasi",Yogyakarta:Graha Ilmu.

[2] Gatot, M. d. (2019), "Sistem Pendidikan Pesantren dan Tantangan Modernitas", Junal Ilmu Pendidikan, 15.

[3] Selviana, W. d. (2019). "Pemodelan Arsitektur Sistem Informasi Perhotelan dengan Kerangka Kerja TOGAF ADM". Jurnal Infromasi Interaktif , 4.

[4] Dadang, T. (2019). "Perancangan Aplikasi Perpustakaan di SMA dan SMK 2 Kota Tasikmalaya". Tasikmalaya: Jumika , 6.

[5] Wahidmurni. (2019, Agustus). Pemaparan metode penelitian kuantitatif. Diambil kembali dari http://repository.uin-malang.ac.id/1985/ 